\title{
EFEKTIFITAS MODEL PEMBELAJARAN OPEN-ENDED TERHADAP PRESTASI BELAJAR MATEMATIKA DITINJAU DARI KREATIVITAS SISWA
}

\author{
Ziyadatush Sholikhah $^{1 \text { (),Tri Jaka Kartana }}{ }^{2)}$, Wikan Budi Utami ${ }^{3)}$ \\ ${ }^{1}$ Program Studi Pendidikan Matematika FKIP Universitas Pancasakti Tegal, ziyadatush31 @ gmail.com
}

\begin{abstract}
Abstrak
Tujuan penelitian ini untuk mengetahui: (1)Ada tidaknya perbedaan antara prestasi belajar siswa yang diajar dengan model pembelajaran open-ended dan prestasi belajar siswa yang diajar dengan model pembelajaran discovery learning, (2)Prestasi belajar matematika siswa manakah yang paling efektif antara siswa yang diajar menggunakan model pembelajaran open-ended dengan siswa yang diajar menggunakan model pembelajaran discovery learning pada siswa yang memiliki kreativitas rendah, (3)Prestasi belajar matematika siswa manakah yang paling efektif antara siswa yang diajar menggunakan model pembelajaran open-ended dengan siswa yang diajar menggunakan model pembelajaran discovery learning pada siswa yang memiliki kreativitas tinggi. Populasi penelitian sebanyak 303 siswa. Instrumen penelitian berupa angket kreativitas belajar matematika dan tes prestasi belajar matematika. Teknik analisis data menggunakan uji t dua pihak, uji t satu pihak. Hasil penelitian:(1) terdapat perbedaan prestasi belajar matematika siswa yang diajar menggunakan model pembelajaran open-ended dengan siswa yang diajar menggunakan model pembelajaran discovery learning, (2)prestasi belajar matematika siswa yang diajar menggunakan model pembelajaran open-ended lebih efektif daripada siswa yang diajar menggunakan model pembelajaran discovery learning ditinjau dari kreativitas rendah, (3)prestasi belajar matematika siswa yang diajar menggunakan model pembelajaran open-ended lebih efektif atau sama dengan siswa yang diajar menggunakan model pembelajaran discovery learning ditinjau dari kreativitas tinggi.
\end{abstract}

Kata Kunci: Efektifitas, model pembelajaran open-ended, pretasi belajar, kreativitas siswa.

Abstract
The purpose of this research is to know: 1) there is difference between student's
learning achievement taught by open-ended learning model and student's learning
achievment taught by discovery learning model, 2) which student's mathematics learning
achievment is most effective between student taught by open-ended learning model with
students who taught using learning discovery learning model on students who have low
creativity, 3) Student learning achievment is the most effective between students who
taught using open-ended learning model with students who were taught using the model
learning discovery learning in students who have high creativity. The research population
is 303 students. The reasearch instrument is questionnaire of creativity of learning
mathematics achievment test. The data analysis technique uses t-test two tailed, t-tes one
tailed. Teh result of research: 1) there are difference of students' mathematics learning
achievment taught using open-ended learning model with students who taught using
discovery learning model, 2) student learning achievment taught using open-ended
learning model more effectively than students taught using learning discovery learning
model from low creativity, 3) student learning achievment taht is taught using open-ended
learning model more effectively or equal to students who are taught using discovery
learning model learning in terms of high creativity


Keywords: Effectiveness, Open-Ended Learning Model, Learning Achievment, Student Creativity.

\section{PENDAHULUAN}

Pendidikan memegang peranan penting dalam menciptakan manusiamanuasia berkualitas. Pendidikan memerlukan inovasi-inovasi yang sesuai dengan kemajuan ilmu pengetahuan dan teknologi tanpa mengabaikan nilai-nilai kemanusiaan. Pendidikan juga dipandang sebagai sarana untuk melahirkan insan-insan yang cerdas, kreatif, terampil, bertanggung jawab, produktif dan berbudi pekerti luhur.

Berdasarkan wawancara peneliti dengan ibu Bukaningrum, S.Pd salah seorang guru matematika di SMP Negeri 1 Adiwerna diperoleh informasi bahwa model pembelajaran yang digunakan oleh guru dalam mengajar kurang inovatif sehingga kurang menggali kreativitas siswa dalam memecahkan masalah, mereka hanya fokus pada hafalan. Kondisi seperti ini membuat siswa kurang aktif dan mandiri. Hal tersebut berdampak pada hasil belajar siswa. Dengan adanya kondisi tersebut, perlu diadakan penelitian untuk memeahkan masalah terkait rendahnya hasil belajar siswa.

Solusi yang paling tepat untuk kondisi tersebut adalah dengan merubah model pembelajaran yang digunakan oleh guru. Trianto menjelaskan model pembelajaran adalah suatu perencanaan atau suatu pola yang digunakan sebagai pedoman dalam merencanakan pembelajaran di kelas atau pembelajaran dalam tutorial (2010:51). Salah satu model pembelajaran yang bisa digunakan adalah model pembelajaran openended. Dengan model ini siswa berpartisipasi lebih aktif dalam pembelajaran dan sering mengekspresikan ideanya (Shoimin, 2014:112).

Model pembelajaran open-ended merupakan proses pembelajaran yang didalamnya, tujuan dan keinginan individu dibangun dan dicapai secara terbuka. (Huda, 2013: 278). Model pembelajaran ini dapat menjadikan siswa berpartisipasi lebih aktif dalam pembelajaran dan juga mempunyai kesempatan lebih banyak dalam memanfaatkan pengetahuan dan keterampilan matematika siswa secara menyeluruh sehingga diharapkan kreativitas siswa dapat berkembang.

Selain dari faktor model pembelajaran, kreativitas juga menentukan hasil belajar. Menurut Munandar (2006: 47) kreativitas adalah kemampuan untuk membuat kombinasi baru, berdasarkan data, informasi, dan unsur-unsur yang ada. Kreativitas pada intinya merupakan kemampuan seseorang untuk melahirkan sesuatu yang baru, baik berupa gagasan maupun karya nyata, baik dalam bentuk ciri-ciri aptitude maupun non aptitude, baik dalam karya yang baru maupun kombinasi dengan hal-hal yang sudah ada, yang semuanya itu relatif berbeda dengan apa yang telah ada sebelumnya. (Hawadi dkk, 2001:5). Mengingat pentingnya kreativitas belajar siswa, maka dalam kegiatan pembelajaran lebih banyak melibatkan kreativitas belajar siswa. Sedangkan siswa itu sendiri hendaknya dapat memotivasi dirinya sendiri untuk ikut kreatif dalam kegiatan belajar mengajar. Dengan adanya kreativitas belajar ini kemungkinan besar prestasi belajar yang dicapai akan memuaskan. 
Penelitian yang dilakukan oleh Pelayati (2014) yang berjudul "Efektifitas Model Pembelajaran Open-Ended Terhadap Prestasi Belajar Matematika Ditinjau dari Motivasi Siswa" mengemukakan bahwa model open-ended lebih baik dari model konvensional sehingga meningkatkan prestasi belajar siswa.

Permasalahan dan tujuan dalam penelitian ini adalah untuk mengetahui: (1)Ada tidaknya perbedaan antara prestasi belajar siswa yang diajar dengan model pembelajaran open-ended dan prestasi belajar siswa yang diajar dengan model pembelajaran discovery learning, (2)Prestasi belajar matematika siswa manakah yang paling efektif antara siswa yang diajar menggunakan model pembelajaran open-ended dengan siswa yang diajar menggunakan model pembelajaran discovery learning pada siswa yang memiliki kreativitas rendah, (3) Prestasi belajar matematika siswa manakah yang paling efektif antara siswa yang diajar menggunakan model pembelajaran open-ended dengan siswa yang diajar menggunakan model pembelajaran discovery learning pada siswa yang memiliki kreativitas tinggi.

Kegunaan dari penelitian ini adalah menjadi masukan dalam pencapaian tujuan pendidikan khususnya pada penerapan model open-ended dalam pembelajaran matematika pada pokok bahasan persamaan linear dua variabel.

\section{KAJIAN TEORI}

\section{Efektifitas}

Menurut Supardi (2013:164) efektivitas adalah usaha untuk mencapai sasaran yang telah ditetapkan sesuai dengan kebutuhan, rencana, dengan menggunakan data, sarana, maupun waktu yang tersedia untuk memperoleh hasil yang maksimal baik secara kuantitatif maupun kualitatif.

Menurut Pipin (Supardi, 2013: 164), Efektifitas dapat diartikan ada efeknya sehingga membawa hasil. Efektifitas adalah terlaksananya kegiatan denga baik, teratur, bersih rapih, sesuai dengan ketentuan dan mengandung unsur-unsur kualitatif dan seni.

Berdasarkan uraian tersebut dapat disimpulkan bahwa efektifitas adalah keberhasilan pengajaran dalam proses belajar untuk meningkatkan pencapaian hasil belajar matematika dengan model pembelajaran openended.

\section{Model pembelajaran Open-ended}

Pembelajaran dengan problem (masalah) terbuka artinya pembelajaran yang menyajikan permasalahan dengan pemecahan berbagai cara (flexibility) dan solusinya juga bisa beragam (multi jawab, fluency). (Shoimin, 2014: 109)

Berikut akan dijelaskan langkahlangkah dalam pembelajaran openended (Shoimin, 2014: 112):

1) Persiapan

Sebelum memulai proses belajar mengajar, guru harus membuat program satuan pelajaran rencana pelaksanaan pembelajaran (RPP), membuat pertanyaan open-ended problems.

2) Pelaksanaan, terdiri atas:

(a)Pendahuluan, yaitu siswa menyimak motivasi yang diberikan oleh guru bahwa yang akan dipelajari berkaitan atau bermanfaat bagi kehidupan sehari-hari sehingga mereka semangat dalam belajar. kemudian siswa menanggapi apersepsi yang 
dilakukan guru agar diketahui pengetahuan awal mereka terhadap konsep-konsep yang akan dipelajari.

(b)Kegiatan inti, yaitu pelaksanaan pembelajaran dengan langkahlangkah berikut: Siswa membentuk kelompok yang terdiri dari empat sampai lima orang, Siswa mendapatkan pertanyaan openended problems, Siswa berdiskusi bersama kelompok mereka masingmasing mengenai penyelesaian dari pertanyaan open-ended problems yang telah diberikan oleh guru, Setiap kelompok siswa melalui perwakilannya, mengemukakan pendapat atau solusi yang ditawarkan kelompoknya secara bergantian, dan Siswa atau kelompok kemudian menganalisis jawaban-jawaban yang telah dikemukakan, mana yang benar dan lebih efektif.

(c)Kegiatan akhir, yaitu siswa menyimpulkan apa yang telah dipelajari. Kemudian kesimpulan tersebut disempurnakan oleh guru.

\section{Evaluasi}

\section{Setelah}

berakhirnya pembelajaran, siswa mendapatkan tugas perorangan (tugas individu) atau pekerjaan rumah (PR) yang berbentuk soal essay. Dan mendapatkan soal ulangan harian yang berbentuk soal pilihan ganda setelah pembahasan materi tentang bab persamaan linear dua variabel yang merupakan evaluasi yang diberikan oleh guru.

Dalam setiap pembelajaran, pasti terdapat kelebihan dan juga kekurangan. Menurut Shoimin (2014: 112) Kelebihan dalam pembelajaran open-ended adalah sebagai berikut: a) Siswa berpartisipasi lebih aktif dalam pembelajaran dan sering mengekspresikan ideanya.

b) Siswa memiliki kesempatan lebih banyak dalam memanfaatkan pengetahuan dan ketempilan matematik secara komprehensif.

c) Siswa dengan kemampuan rendah dapat merespon permasalahan dengan cara mereka sendiri.

d) Siswa secara instrinsik termotivasi untuk memberi bukti atau penjelasan.

e) Siswa memiliki pengalaman banyak untuk menemukan sesuatu dalam menjawab permasalahan.

Kekurangan dalam pembelajaran ini menurut Shoimin (2014:112) adalah sebagai berikut :

a) Membuat dan menyiapkan masalah yang bermakna bagi siswa bukanlah pekerjaan mudah.

b) Mengemukakan masalah yang langsung dapat dipahami siswa sangat sulit sehingga banyak yang mengalami kesulitan bagaimana merespons permasalahan yang diberikan.

c) Siswa dengan kemampuan tinggi bisa merasa ragu atau mencemaskan jawaban mereka.

d) Mungkin ada sebagian siswa yang merasa bahwa kegiatan belajar mereka tidak menyenangkan karena kesulitan yang dihadapi.

\section{a. Prestasi belajar matematika}

Menurut Susongko (2013:9), prestasi belajar mengacu pada perilaku kognitif yang bervariasi dari ingatan sederhana tentang fakta hingga tipe kompleks dari berpikir. Prestasi belajar terjadi pada waktu singkat, seperti halnya setelah selesai pelajaran, setelah satu semester atau satu kursus. 
Prestasi belajar adalah kemampuan-kemampuan yang dimiliki siswa setelah ia mengalami pengalaman belajarnya (Hari, dkk, 2014:5). Dengan demikian prestasi belajar mampu menunjukkan sejauh mana efektifitas pada ranah kognitif dari pembelajaran yang telah dilaksanakan.

Dari uraian tersebut, dapat disimpulkan bahwa prestasi belajar adalah suatu ketercapaian suatu kompetensi kognitif setelah proses pembelajaran dalam waktu yang singkat.

Matematika adalah ilmu yang sebenarnya mendidik anak agar berfikir logis, kritis, sistematis, memiliki sifat obyektif, jujur, disiplin dalam memecahkan permasalahan baik dalam bidang matematika, bidang lain maupun dalam kehidupan sehari - hari. (Putriyani, 2012: 1)

Pendapat lain tentang matematika adalah bahasa yang menjelaskan tentang pola-pola baik di alam dan maupun pola yang ditemukan melalui pikiran, simbol-simbol yang berkenan dengan konsep abstrak, penalarannya bersifat deduktif dan kebenarannya bersifat universal sesuai semestanya.

Matematika diajarkan di Pendidikan Dasar (SD dan SMP) dan Pendidikan Menengah (SMU dan SMK). Matematika tersebut terdiri atas bagian-bagian matematika yang dipilih guna menumbuh kembangkan kemampuan-kemampuan dan membentuk pribadi serta berpandu pada perkembangan IPTEK. (Suherman. 2001:54)

Berdasarkan pengertian matematika dari beberapa sumber maka dapat disimpulkan bahwa matematika adalah ilmu tentang pola-pola baik di alam maupun yang ditemukan melalui pikiran guna menumbuhkembangkan kemampuan-kemampuan dan membantuk pribadi serta berpandu pada perkembangan IPTEK.

Berdasarkan pengertian prestasi belajar dan matematika yang telah di uraikan maka dapat disimpulkan prestasi belajar matematika adalah suatu ketercapaian suatu kompetensi kognitif setelah proses pembelajaran dalam waktu yang singkat terhadap ilmu tentang pola-pola baik di alam maupun yang ditemukan melalui pikiran guna menumbuhkembangkan kemampuan-kemampuan dan membantuk pribadi serta berpandu pada perkembangan IPTEK.

\section{b. Kreativitas}

Menurut Munandar (2006: 47) menyatakan bahwa "kreativitas adalah kemampuan untuk membuat kombinasi baru, berdasarkan data, informasi, dan unsur-unsur yang ada.

Creative achievement reflects a rare capacity for developing insights, sensitivities, and appreaciations in a circumscribed content area of intelectual or artistic activity. (Hamalik, 2008: 179)

Menurut Moreno, yang penting dalam kreativitas itu bukanlah penemuan sesuatu yang belum pernah diketahui orang sebelumnya, melainkan bahwa produk kreativitas itu merupakan sesuatu yang baru bagi diri sendiri dan tidak harus merupakan sesuatu yang baru bagi 
orang lain atau dunia pada umumnya, misalnya seorang siswa menciptakan untuk dirinya sendiri suatu hubungan baru dengan siswa/orang lain. (Slameto, 2010: 146).

Kreativitas merupakan karakter manusia yang masih dan sulit di definisikan (Susongko, 2013:20). Pada lingkungan sekolah kita dapat mengobservasi kreativitas yang sering berbeda pada setiap siswa.

Berdasarkan pandangan dari sejumlah ahli tersebut daat disimpulkan bahwa kreativitas adalah suatu kemampuan seseorang untuk menciptakan sesuatu hal yang baru dan merupakan karakter manusia yang masih sulit didefinisikan.

Para siswa dibimbing agar memiliki kemampuan kreativitas, mampu berpikir kritis, dan mampu memecahkan masalah. Karena itu, melalui proses belajar tertentu, diupayakan tercapainya tujuan-tujuan tersebut. Guru perlu menyediakan kondisi-kondisi belajar yang memungkinkan terjadinyapenambahan aspek keluwesan, keaslian, dan kuantitas dari abilite kreativitas yang dimiliki oleh para siswa. Adapun prosedur mengembangkan kreativitas diantaranya :

1) Mengklasifikasikan jenis masalah yang akan disajikan kepada siswa

2) Mengembangkan dan menggunakan keterampilanketerampilan pemecahan masalah

3) Ganjaran bagi prestasi belajar kreatif.

\section{METODE PENELITIAN}

\section{Jenis Penelitian}

Dalam penelitian ini menggunakan jenis pendekatan kuantitatif yang berdasarkan bentuk rumusan hipotesis yang akan diuji. Pada penelitian ini akan membandingkan model pembelajaran manakah yang paling efektif antara siswa yang diajar menggunakan model pembelajaran open-ended dengan model discovery learning ditinjau dari kreativitas siswa terhadap prestasi belajar matematika.

\section{Waktu dan Tempat Penelitian}

Penelitian ini dilaksanakan pada tanggal 2 Januari sampai 17 Februari 2017 di Kelas VIII SMP Negeri 1 Adiwerna.

\section{Target/ subjek penelitian}

Penelitian ini dilakukan pada siswa kelas VIII semester II SMP Negeri 1 Adiwerna tahun pelajaran 2016/2017 yang berjumlah 303 siswa yang terdiri atas Sembilan kelas yaitu VIII A, VIII B, VIII C, VIII D, VIII E, VIII F, VIII G, VIII H dan VIII I. Dalam pengambilan sampel digunakan teknik cluster random sampling sehingga diperoleh kelas VIII C sebagai kelas eksperimen, kelas VIII E sebagai kelas kontrol dan VIII D sebagai kelas uji coba.

\section{Instrumen Penelitian}

Instrumen penelitian adalah suatu alat yang digunakan untuk mengukur fenomena alam maupun sosial yang diamati Sugiyono (2015:148). Instrumen pada penelitian ini terdiri angket kreativitas siswa dan tes prestasi belajar matematika pada materi pokok persamaan linear dua variabel. Sebelum instrumen tes 
prestasi belajar diberikan siswa terlebih dahulu dilakukan uji coba instrumen (tes prestasi belajar) untuk melihat validitas dan realibitas instrumen tersebut.

\section{Metode Pengumpulan Data}

Teknik pengumpulan data dalam penelitian ini menggunakan metode dokumentasi dan metode angket. Metode dokumentasi digunakan untuk mendapatkan data prestasi belajar matematika siswa, data yang dimaksud adalah nilai Ulangan Akhir Semester (UAS) kelas VIII semester 1 pada mata pelajaran matematika tahun 2016/2017. Metode angket digunakan untuk mengetahui kreativitas belajar siswa terhadap mata pelajaran matematika materi pokok persamaan linear dua variabel.

\section{Teknik Analisis Data}

Sebelum dilakukan uji hipotesis, maka dilakukan uji prasyarat terlebih dahulu yaitu uji normalitas menggunakan uji Liliefors (Sudjana, 2005: 466-467) dan uji homogenitas menggunakan uji Bartlet (Sudjana, 2005: 261-265).

Apabila uji prasyarat telah dilakukan dan data telah memenuhi syarat, maka selanjutnya dilakukan pengujian hipotesis. Dalam penelitian ini digunakan uji $\mathrm{t}$ dua pihak dan uji $\mathrm{t}$ satu pihak.

\section{HASIL DAN PEMBAHASAN}

\section{Data Kreativitas Siswa}

Berdasarkan hasil uji tes angket pada kelas eksperimen dan kontrol didapatkan rata-rata nilai skala 61 , maka dapat dikelompokan:

$0-61$ : Kreativitas siswa rendah $62-96$ : Kreativitas siswa tinggi

Tabel 1. Data Kreativitas Siswa Kelas Eksperimen

\begin{tabular}{|c|c|c|c|c|}
\hline No & Nilai & Keterangan & $\begin{array}{c}\text { Jumlah } \\
\text { Siswa }\end{array}$ & $\begin{array}{l}\text { Frekuensi } \\
\text { relatif }(\%)\end{array}$ \\
\hline 1 & $40-61$ & Rendah & 16 & 47,06 \\
\hline 2 & $62-80$ & Tinggi & 18 & 52,94 \\
\hline 3 & \multicolumn{2}{|c|}{ Jumlah } & 34 & 100 \\
\hline
\end{tabular}

Berdasarkan Tabel 1 dapat diketahui bahwa banyaknya siswa kelas eksperimen dengan nilai kreativitas antara 40-61 sejumlah 47,05\% dan tergolong kelompok siswa dengan kreativitas rendah. Sedangkan banyaknya siswa yang mendapat nilai antara 62-80 sejumlah 52,94\% dan tergolong kelompok siswa dengan kreativitas tinggi.

Tabel 2. Data Kreativitas Siswa Kelas Kontrol

\begin{tabular}{|c|c|c|c|c|}
\hline No & Nilai & Keterangan & Jumlah Siswa & $\begin{array}{c}\text { Frekuensi } \\
\text { relatif(\%) }\end{array}$ \\
\hline 1 & $46-61$ & Rendah & 19 & 55,88 \\
\hline 2 & $62-80$ & Tinggi & 15 & 44,12 \\
\hline 3 & \multicolumn{2}{|c|}{ Jumlah } & 34 & 100 \\
\hline
\end{tabular}

Berdasarkan Tabel 2 dapat kreativitas siswa antara 46-61 diketahui bahwa banyaknya siswa sejumlah $47,06 \%$ dan tergolong kelas kontrol yang mendapat nilai kelompok siswa dengan kreativitas 
rendah. Sedangkan banyaknya siswa yang mendapat nilai antara 62-80 sejumlah $52,94 \%$ dan tergolong kelompok siswa dengan kreativitas

2. Data Prestasi belajar matematika siswa tinggi.

Tabel 3. Data prestasi belajar matematika ditinjau dari kreativitas

\begin{tabular}{|c|c|c|c|c|c|}
\hline \multirow{2}{*}{ No } & \multirow{2}{*}{ Data } & \multicolumn{4}{|c|}{ Model Pembelajaran } \\
\cline { 3 - 6 } & & \multicolumn{2}{|c|}{ Open-ended } & \multicolumn{2}{c|}{ Discovery learning } \\
\cline { 3 - 6 } & & $\begin{array}{c}\text { Kreativitas } \\
\text { tinggi }\end{array}$ & $\begin{array}{c}\text { Kreativitas } \\
\text { rendah }\end{array}$ & $\begin{array}{c}\text { Kreativitas } \\
\text { tinggi }\end{array}$ & $\begin{array}{c}\text { Kreativitas } \\
\text { rendah }\end{array}$ \\
\hline 1 & Mean & 86,11 & 85 & 76,32 & 74,33 \\
\hline 2 & Median & 87,50 & 85 & 75 & 75 \\
\hline 3 & Max & 100 & 100 & 90 & 95 \\
\hline 4 & Min & 65 & 60 & 50 & 50 \\
\hline 5 & Jangkauan & 35 & 40 & 40 & 45 \\
\hline 6 & Modus & 85 & 100 & 75 & 80 \\
\hline 7 & Std. Deviasi & 11,318 & 13,540 & 8,307 & 11,872 \\
\hline 8 & Koef. Variasi & 0,131 & 0,160 & 0,109 & 0,160 \\
\hline
\end{tabular}

Berdasarkan Tabel 3 dapat diketahui perbedaan data dari masingmasing perlakuan dan masing-masing kelompok, pada siswa yang diajar menggunakan model open-ended dengan kreativitas tinggi diketahui rata-rata 86,11 dengan koefisien variansi 0,131 dan menggunakan model open-ended dengan kreativitas rendah diketahui rata-rata 85 dengan koefisien variansi 0,160 Sedangkan siswa yang diajar model discovery learning dengan kreativitas tinggi diketahui rata-rata 74,33 dengan koefisien variansi 0,109 dan model discovery learning dengan kreativitas rendah rata-ratanya 74,33 dengan koefisien variansi 0,160 . Perbedaan ini disebabkan karena pada kelas eksperimen siswa lebih aktif, sehingga pembelajaran dapat maksimal. Sedangkan pada kelas kontrol siswa lebih pasif sehingga pembelajaran kurang maksimal.

Dari uraian data hasil statistik deskriptif tersebut, maka dapat disimpulkan bahwa prestasi belajar matematika siswa kelas eksperimen lebih tinggi dibandingkan dengan prestasi kelas kontrol.

\section{Hasil Pengujian Hipotesis}

Sebelum melakukan uji hipotesis, dilakukan pengujian data prestasi belajar matematika siswa yang diperoleh melalui uji normalitas. Adapun hasil pengujiannya sebagai berikut:

T abel 4. Hasil Uji Normalitas

\begin{tabular}{|c|c|c|c|}
\hline Kelas & $\mathbf{L}_{\text {hitung }}$ & $\mathbf{L}_{\text {tabel }}$ & Kesimpulan \\
\hline Eskperimen & 0,019 & 0,152 & Normal \\
\hline Kontrol & 0,146 & 0,152 & Normal \\
\hline
\end{tabular}


Dalam penelitian ini digunakan uji t antara kreativitas siswa dengan prestasi belajar matematika. Analilis ini dimaksudkan untuk mengetahui ada tidaknya perbedaan antara prestasi belajar siswa yang diajar dengan model pembelajaran open-ended dan prestasi belajar siswa yang diajar dengan model pembelajaran discovery learning dan mdel pembelajaran manakah yang lebih efektif.

Hasil perhitungan hipotesis pertama dengan uji $t$ dua pihak $t_{\text {hitung }}=3,751$ dan $t_{\text {tabel }}=1,96$ dengan taraf signifikan $5 \%$ dan $\mathrm{dk}=66$, Karena $t_{\text {hitung }}$ tidak terletak di daerah $H_{0}$, sehingga $H_{a}$ diterima dan $H_{0}$ ditolak. Berarti ada perbedaan prestasi belajar pada siswa yang diajar dengan model pembelajaran open-ended dengan siswa yang diajar dengan pembelajaran discovery learning. Berdasarkan hasil analisis diketahui bahwa terdapat perbedaan rata-rata prestasi belajar matematika dari kedua perlakuan pada kelas eksperimen dan kelas kontrol, maka analisis dilanjutkan dengan menggunakan uji $\mathrm{t}$ satu pihak kanan untuk menguji hipotesis yang kedua, dan uji t pihak kiri untuk menguji hipotesis yang ketiga. Berdasarkan perhitungan diperoleh $t_{\text {hitung }}=2,333$ dan $t_{\text {tabel }}=$ 1,645 dengan $\mathrm{dk}=68-2=66$ dan taraf signifikan $5 \%$ karena $t_{\text {hitung }}>t_{\text {tabel }}$ maka $H_{0}$ ditolak, dengan kata lain $H_{a}$ diterima, sehingga dapat dikatakan prestasi belajar matematika siswa yang diajar dengan model pembelajaran open-ended lebih efektif dari siswa yang diajar dengan pembelajaran discovery learning yang mempunyai tingkat kreativitas rendah. Kemudian dari perhitungan selanjutnya menggunakan uji-t pihak kiri diperoleh $t_{\text {hitung }}=3,013$. dan $t_{\text {tabel }}=$ 1,645 dengan $\mathrm{dk}=68-2=66$ dan taraf signifikan 5\%. Karena $t_{\text {hitung }}>$ $t_{\text {tabel }}$ maka $H_{0}$ diterima artinya $H_{a}$ ditolak, sehingga dapat dikatakan prestasi belajar matematika siswa yang diajar dengan model pembelajaran open-ended lebih efektif dari siswa yang diajar dengan pembelajaran discovery learning yang mempunyai tingkat kreativitas tinggi.

\section{Pembahasan}

Berdasarkan hasil penelitian ini dengan menggunakan uji $t$ dua pihak menunjukkan terdapat perbedaaan prestasi belajar siswa yang diajar menggunakan model pembelajaran open-ended dengan discovery learning. Hasil yang diperoleh dari nilai tes prestasi belajar pada materi persamaan linear dua variabel siswa yang diajar menggunakan model pembelajaran open-ended lebih tinggi dari pada siswa yang diajar secara discovery learning. Hal ini dibuktikan dengan perbedaan koefisien variansi, semakin kecil koefisien variansinya maka semakin baik hasilnya. Pada kelas eksperimen siswa yang diajar menggunakan model pembelajaran open-ended mempunyai koefisien variansi 0,143. Sedangkan kelas kontrol yang diajar menggunakan model pembelajaran discovery learning mempunyai koefisien variansi 0,263. Model pembelajaran open-ended dapat memberikan kebebasan kepada siswa dalam menyampaikan gagasan dan pendapatnya, sehingga dapat meningkatkan berpikir kritis, sistematis, logis dan juga kreatif. Dengan demikian siswa berpartisipasi lebih aktif dalam proses pembelajaran.

Dalam penelitian ini, faktor dari dalam siswa juga diperhatikan. Kreativitas sebagai salah satu dasar dalam mengembangkan potensi yang 
dimiliki siswa yang menjadi tinjauan dalam penelitian ini. Berdasarkan hasil pengujian hipotesis menggunakan uji $\mathrm{t}$ satu pihak kiri jika ditinjau dari kreativitas rendah didapatkan bahwa prestasi belajar matematika siswa yang diajar dengan menggunakan model pembelajaran open-ended lebih efektif daripada prestasi belajar matematika siswa yang diajar dengan menggunakan model pembelajaran discovery learning. Hal itu juga ditunjukkan dengan nilai rata-rata prestasi belajar matematika siswa yang diajar dengan menggunakan model pembelajaran open-ended mencapai 85,29 sedangkan nilai rata-rata prestasi belajar matematika siswa yang diajar menggunakan model pembelajaran discovery learning hanya mencapai 72,81. Sedangkan jika ditinjau dari kreativitas tinggi berdasarkan hasil pengujian menggunakan uji t satu pihak kanan didapatkan bahwa prestasi belajar matematika siswa yang diajar dengan menggunakan model pembelajaran open-ended lebih baik daripada prestasi belajar matematika siswa yang diajar dengan menggunakan model pembelajaran discovery learning. Hal itu juga ditunjukkan dengan nilai ratarata prestasi belajar matematika siswa yang diajar dengan menggunakan model pembelajaran open-ended mencapai 87,65 sedangkan nilai ratarata prestasi belajar matematika siswa yang diajar menggunakan model pembelajaran discovery learning hanya mencapai 77,78 .

\section{SIMPULAN DAN SARAN}

\section{Simpulan}

Berdasarkan hasil penelitian, maka dapat disimpulkan bahwa :

a) Terdapat perbedaan prestasi belajar matematika siswa yang diajar menggunakan model pembelajaran open-ended dengan siswa yang diajar menggunakan model pembelajaran discovery learning.

b) Prestasi belajar matematika siswa yang diajar menggunakan model pembelajaran open-ended lebih efektif daripada siswa yang diajar menggunakan model pembelajaran discovery learning ditinjau dari kreativitas rendah.

c) Prestasi belajar matematika siswa yang diajar menggunakan model pembelajaran open-ended lebih baik atau sama dengan siswa yang diajar menggunakan model pembelajaran discovery learning ditinjau dari kreativitas tinggi..

\section{Saran}

Berdasarkan hasil penelitian, ada beberapa saran yang dapat dikemukakan sebagai berikut :

a) Guru perlu mencoba model pembelajaran open-ended sehingga siswa dalam menerima materi pelajaran tidak merasa jenuh.

b) Siswa perlu dilibatkan dalam pembelajaran agar suasana lebih hidup sehingga siswa tidak hanya menerima pengetahuan tapi mencari pengetahuan, sehingga akan selalu diingatnya.

c) Hendaknya dapat menjadi bahan masukan bagi sekolah dalam upaya meningkatkan kualitas pendidikan yang mengarah pada pencapaian prestasi belajar matematika yang optimal dengan memperhatikan kreativitas siswa serta sumber sumber pembelajaran yang ada perlu dikembangkan sehingga pengetahuan siswa juga bisa berkembang. 


\section{DAFTAR PUSTAKA}

Arikunto, S. (2006). Prosedur Penelitian. Jakarta: Rineka Cipta.

Arikunto, S. (2013). Dasar-dasar Evaluasi Pendidikan (Edisi 2). Jakarta: Bumi Aksara.

Hamdani. (2011). Strategi Belajar Mengajar. Bandung: Pustaka Setia.

Hari, I., A., Widia, Syahruddin, D., K., T. (2014). Pengaruh model Problem Based Instruction (PBI) Terhadap Prestasi Belajar IPS Siswa KelasV SD di Kecamatan Sukasada Tahun Pelajaran 2013/2014. eJournal MIMBAR PGSD Universitas Pendidikan Ganesha Jurusan PGSD Vol: 2 No:1.

Harmalik, O. (2008). Perencanaan Pengajaran Berdasarkan Pendekatan Sistem. Jakarta: Bumi Aksara.

Hasbullah. (2005). Dasar-dasar Ilmu Pendidikan. Jakarta: PT Raja Grafindo Persada.

Huda, M. (2004). Model-model Pengajaran dan Pembelajaran. Yogyakarta: Pustaka Belajar.

Ilmiana, E, Suhartati, Hidayat, M. (2016). "Ketuntasan Belajar Siswa melalui Penerapan Model Discovery Learning dengan Pendekatan OpenEnded pada Materi Persamaan Linear Dua Variabel Siswa Kelas VIII SMP Negeri 10 Banda Aceh". Jurnal Ilmiah Mahasiswa Pendidikan Matematika. Volume 1, Nomor 1, 9-21.

Munandar S. C. Utami. (2006). Mengembangkan Bakat dan Kreativitas Anak Sekolah Petunjuk Bagi Para Guru dan
Orang Tua. Jakarta: Gramedia Widia Sarana Indonesia.

Notoatmodjo, S. (2003). Pendidikan dan Perilaku Kesehatan. Jakarta: PT Rineka Cipta.

Ponoharjo. (2015). Penelitian Pendidikan Matematika. Tegal: Universitas Pancasakti Tegal.

Rusman. (2011). Model-model Pembelajaran

Mengembangkan

Profesionalisme Guru. Jakarta: Rajawali.

Setiani, A dan Priansa, D., J. (2015). Manajemen Peserta Didik dan Model Pembelajaran: Cerdas, Kreatif, dan Inovatif. Bandung: Alfabeta.

Shoimin, A. (2014). 68 Model Pembelajaran Inovatif dalam Kurikulum 2013. Yogyakarta: Ar-Ruzz Media.

Slameto. (2010). Belajar dan Faktorfaktor yang Mempengaruhinya. Jakarta: Rineka Cipta.

Sugiyono. (2012). Metode Penelitian Pendidikan. Bandung: Alfabeta.

Sudjana. 2005. Metode Statistik. Bandung : Tarsito.

Suherman, E dkk. (2001). Strategi Pembelajaran Matematika Kontemporer. Bandung: JICAUniversitas Pendidikan Indonesia (UPI).

Sumaatmadja, N. (2002). Pendidikan manusia manusiawi. Bandung: Alfabeta.

Supardi. (2013). Sekolah Efektif Konsep Dasar dan Praktiknya. Jakarta: Raja Wali.

Susongko, P. (2015). Pengantar Metodologi Penelitian Pendidikan. Tegal: Universitas Pancasakti Tegal. 
Susongko, P. (2013). Penilaian Hasil Belajar. Tegal: Universitas Pancasakti Tegal.

Syah. 2004. Psikologi Pendidikan dengan
Pendekatan Baru. Bandung:

PT Remaja Rosdakarya.

Trianto. (2010). Model Pembelajaran

Terpadu. Jakarta: Bumi Aksara. 